\title{
DEVELOPMENT OF INNOVATIVE BRAKE SYSTEM FOR ROLLING STOCK
}

\author{
Taško Smileski ${ }^{1}$, Gligorče Vrtanoski ${ }^{2}$ \\ ${ }^{1}$ MSc Student at the Faculty of Mechanical Engineering, "Ss. Cyril and Methodius" University in Skopje, \\ Karpoš II bb, P.O. box 464, 1001 Skopje, Republic of N6rth Macedonia \\ ${ }^{2}$ Faculty of Mechanical Engineering, ":Ss. Cyril and Methodius” University in Skopje, \\ P.O. Box 464, MK-1001, Skopje, Republic of North Macedonia \\ gligorche.vrtanoski@mf.edu.mk
}

\begin{abstract}
A b s t r a c t: In this paper is shown the importance of introducing innovative products in railway industry, especially when it comes to products from which depends the railway traffic safety, like the brake systems. These brake systems have the essential function of decelerating and stoping of rolling stock. Because the brake systems are a subject of large static and dynamic loads in external conditions, the development of this type of system is a long and complex process. In this paper is shown one part of innovative brake system development by using computer simulation.
\end{abstract}

Key words: railway; development; brake system; innovation; simulation

\section{РАЗВОЈ НА ИНОВАТИВЕН СОПИРАЧКИ СИСТЕМ ЗА ЖЕЛЕЗНИЧКИ ПРЕВОЗНИ СРЕДСТВА}

А п с т р а к т: Во трудот е прикажана важноста на воведување иновативни производи во железничката индустрија, особено кога се работи за производи од коишто зависи безбедноста во железничкиот сообраќај како што се сопирачките системи. Овие сопирачки системи имаат есенцијална функција за намалување на брзината и сопирање на железничките превозни средства. Бидејќи сопирачките системи се изложени на големи статички и динамички оптоварувања во надворешни услови, развојот на еден ваков систем претставува долг и сложен процес. Во трудот е прикажан еден сегмент од развојот на иновативен сопирачки систем со користење компјутерска симулација.

Клучни зборови: железница; развој; сопирачки систем; иновација; симулација

\section{INTRODUCTION}

Rail transport provides a very important role in society, not only to enable large number of people to get to work every day, but also for transport of materials and goods. The development of rail transport in recent decades goes in direction of increasing the speed and loading capabilities of rolling stock. This directly affects the development of brake technology [5]. The brake system has an essential function of reducing the speed and braking of rolling stock for the minimum possible time [3]. The process of braking is of great importance for the safety of rail traffic. As railway operators focus on the need for greater improvements in efficiency and safety, there is still a considerable need for advancements of railway brake systems [2, 6]. Several types of brake systems are used in the railways. Most commonly are used compressed air brake systems, called pneumatic brake systems [1].

The development of new products contributes to the growth of companies, affects profits and is a key factor in business planning [8]. Innovations are key to the survival of companies. The meaning of the word innovation is introduction of something new - change, while invention refers to something that has never been made before [11]. Throughout the world there is a popular model - from imitation 
to innovation, and then generating an invention [12]. Research has shown that investment in product development is relatively inexpensive and free from high risk but can lead to a major competitive advantage in terms of cost savings, customer engagement and increased profits in a company [4].

In the process of developing a brake system, the most important segment is to use the most advanced softwares, methods and techniques. The simulation of multi-body dynamics, together with finite-element simulation, is one of the key methods for design, homologation and research in the field of railway and similar vehicles [7]. The optimal combination of simulation tools, field trials and testing equipment can be the right way to accelerate the introduction of innovative technologies, reduce costs and increase safety, performance and econo- mic competitiveness in rail transport [14]. Multibody dynamic simulation can replace very expensive tests and measurements of the railway vehicle. Nowadays almost every newly developed railway vehicle has undergone a multi-body simulation. The obtained results from the simulation will indicate whether the brake system meets the UIC standard criteria for the rail and whether it meets the requirements of the cutomers.

\section{MODEL OF BRAKE SYSTEM}

\subsection{Types of brake systems}

From a technical point of view, there are two main groups of brakes for rail vehicles: adhesion and non-adhesion brakes (Figure 1).

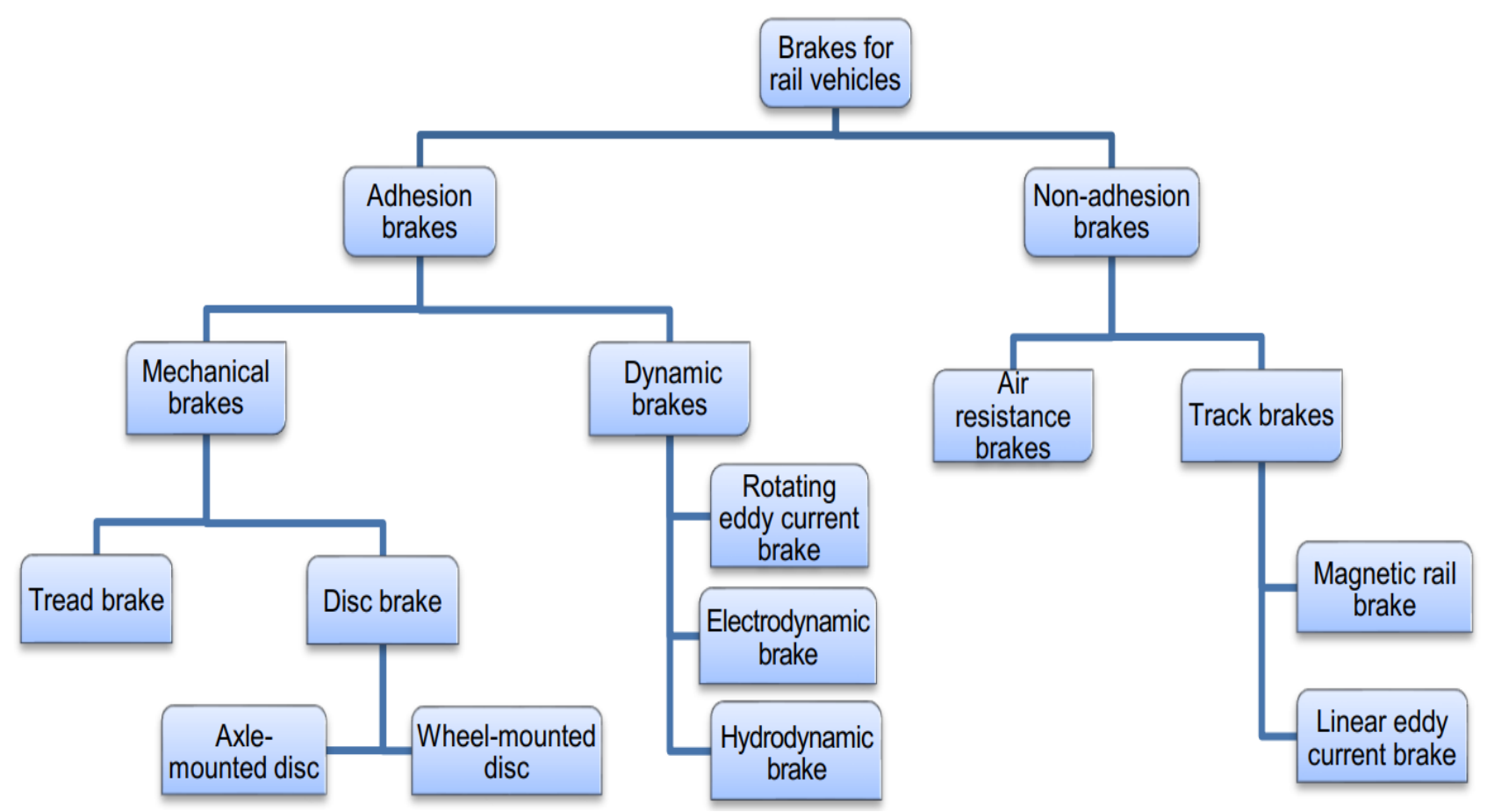

Fig. 1. Types of brakes for rail vehicles [13]

Adhesion brakes include mechanical brakes and dynamic brakes. Mechanical brakes are divided into tread brakes and disc brakes. On disc brakes, the disc can be axle-mounted or wheel-mounted. Dynamic brakes include rotating eddy current brakes, electrodynamic brakes and hydrodynamic brakes.

Non-adhesion brakes include air resistance brakes and track brakes. The second type of brakes includes: magnetic rail brakes and linear eddy current brakes.
Brake systems for rail vehicles can also be classified according to the activation method in the following categories [3]:

- pneumatic brakes.

- electrodynamic brakes.

- mechanical brakes.

- electromagnetic brakes.

Pneumatic brakes can be classified into two types:

- vacuum brakes.

- compressed air brakes. 
From all these braking systems, the focus in this paper is placed on pneumatic tread brake systems with compressed air.

\subsection{Description of conventional brake system for freight wagons}

The conventional brake system for freight wagons (excluding pneumatic components) consists of these main components: brake cylinder, slack adjuster, pull rods, brake riggings, brake shoe holders and brake shoes. The schematic view of this brake system is shown in Figure 2.

The function of the brake system is achieved by applying pressure in the brake cylinder (1) from which the generated force is transfered through brake riggings (3) and slack adjuster (2) onto the brake shoe holders (4). From the brake shoe holders, the brake force is transferred on the brake shoes (5) and onto the wheels of the wagon. The slack adjuster (2) has a function to compensate for the wear of the brake shoes (5) and wheels. When the brake shoes or wheels are wearing, the brake cylinder has larger stroke than nominal and it is activating the trigger (6) of the slack adjuster which decreases the lenght of the slack adjuster and compensates the wearing. The gap between the shoes and wheels can be adjusted by changing the length of the trigger (6).

The simple design of the conventional brake system is the reason why this system is dominant in the rail freight market worldwide until the introduction of integrated bogie brake systems.

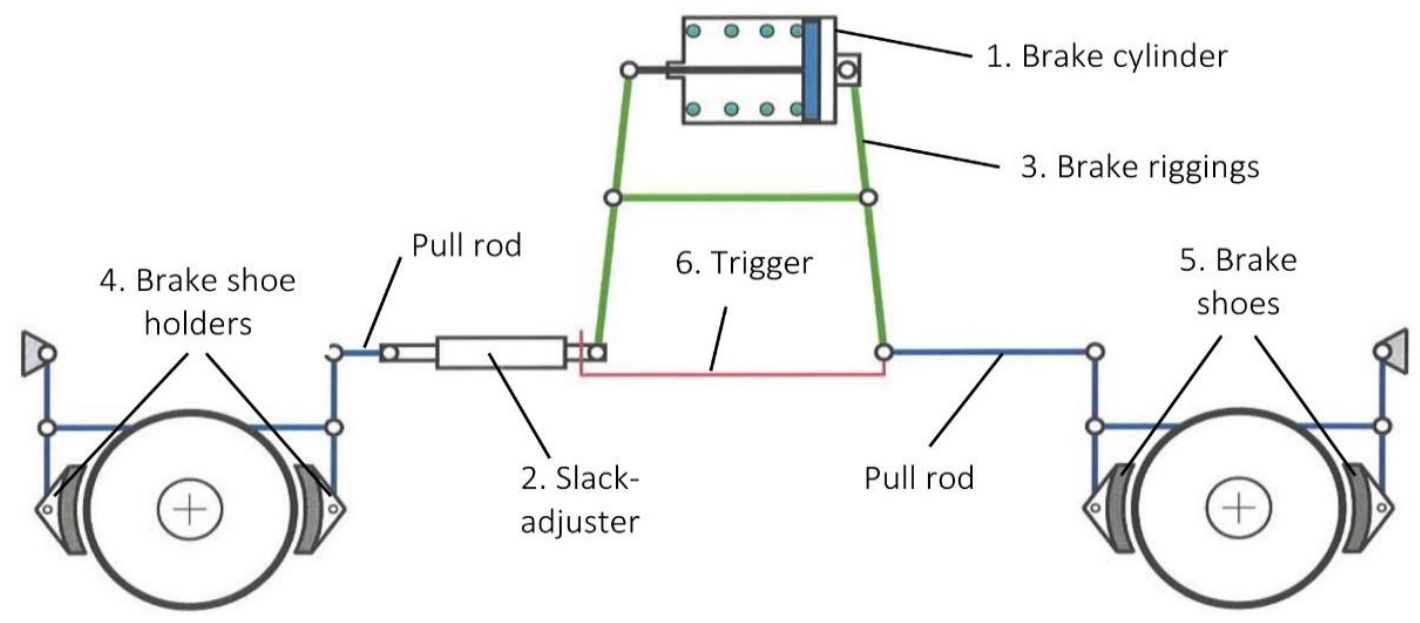

Fig. 2. Shematic view of conventional brake system [6]

\subsection{Model of innovative brake system}

As railway operators focus on the need for greater improvements in efficiency and safety, there is a significant need for improvements of the brake systems [2,6]. Advanced brake systems lead to many benefits like improvements in the load capacity, increasing the safety and optimized life cycle costs.

The proposed model of the innovative brake system IBB10 is intended for use in freight wagons and has the lowest weight on the market. It consists of a brake cylinder which through a system of levers and slack adjusters, transfers the force on the brake shoe holders and onto the brake shoes that come in frictional contact with the wheels of the wagon. The brake force is achieved through the brake cylinder and multiplied through the levers. Two slack adjusters serve to compensate the wear of the brake shoes and wheels. This brake system design allows easy assembly and disassembly on each subassembly separately, which is a great advantage in maintenance and repair of the system. The innovative IBB10 brake system can be fitted between the wheels of a bogie type Y25 or similar and it fits the standard built-in measures as the conventional brake system. The function of the innovative brake system is to provide approximately equal brake force on all four wheels at the same time. The design is characterized by the use of a brake cylinder with (or without) a hand brake and two slack adjusters for automatical adjustment of the gap between the wheels and brake shoes.

In Figure 3 is shown the innovative system IBB10 without hand brake. This model of the innovative IBB10 system is the base for all other variants. 


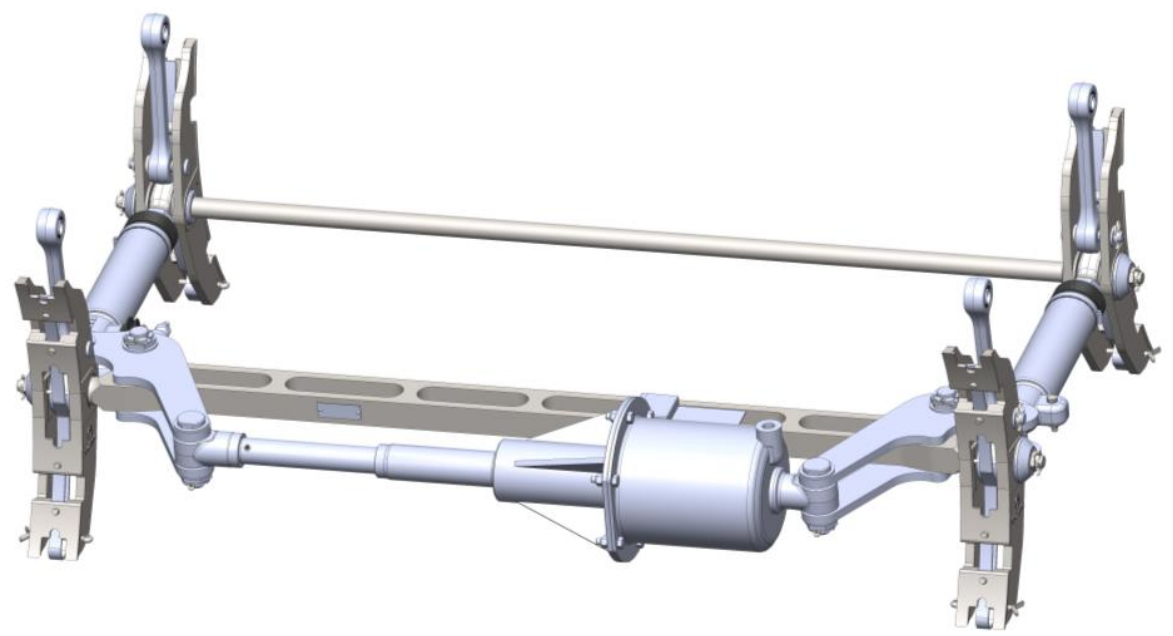

Fig. 3. Model of innovative brake system IBB10 without hand brake [6]

The service brake force is calculated according to the following equation (1):

$$
F=\left(p \cdot S \cdot 10-F_{B}\right) \cdot i \cdot \eta-F_{S}(\mathrm{~N})
$$

where:

$$
\begin{aligned}
& p \text { - brake cylinder pressure (bar); } \\
& S \text {-effective piston area }\left(\mathrm{cm}^{2}\right) ; \\
& F_{B} \text { - return spring force }(\mathrm{N}) ; \\
& i \text { - lever ratio; } \\
& \eta-\text { efficiency; } \\
& F_{S} \text { - slack adjuster counterforce }(\mathrm{N}) .
\end{aligned}
$$

From all the listed factors that influence the service brake force, only the brake cylinder pressure is a variable, while all other factors are constant. Taking into account the fact that for different types of freight wagons a different brake force is needed and the pressure $p$ is defined according to the UIC standard, from design point of view the ratio of the levers $i$ can be changed.

The innovative brake system IBB10 is installed on one bogie, and since one freight wagon usually has two bogies, in most cases, two IBB10 systems will be installed per wagon as a set. Because each freight wagon should have parking option when is removed from the train composition (or because some other reasons), at least one IBB10 unit must have a parking hand brake. In Figure 4 is shown a variant of the innovative brake system IBB10 with a platform hand brake. This brake system with platform hand brake has the same function as IBB10 without hand brake, but with added function of the hand application of a parking brake. The application of the platform hand brake is done from the platform of the wagon.

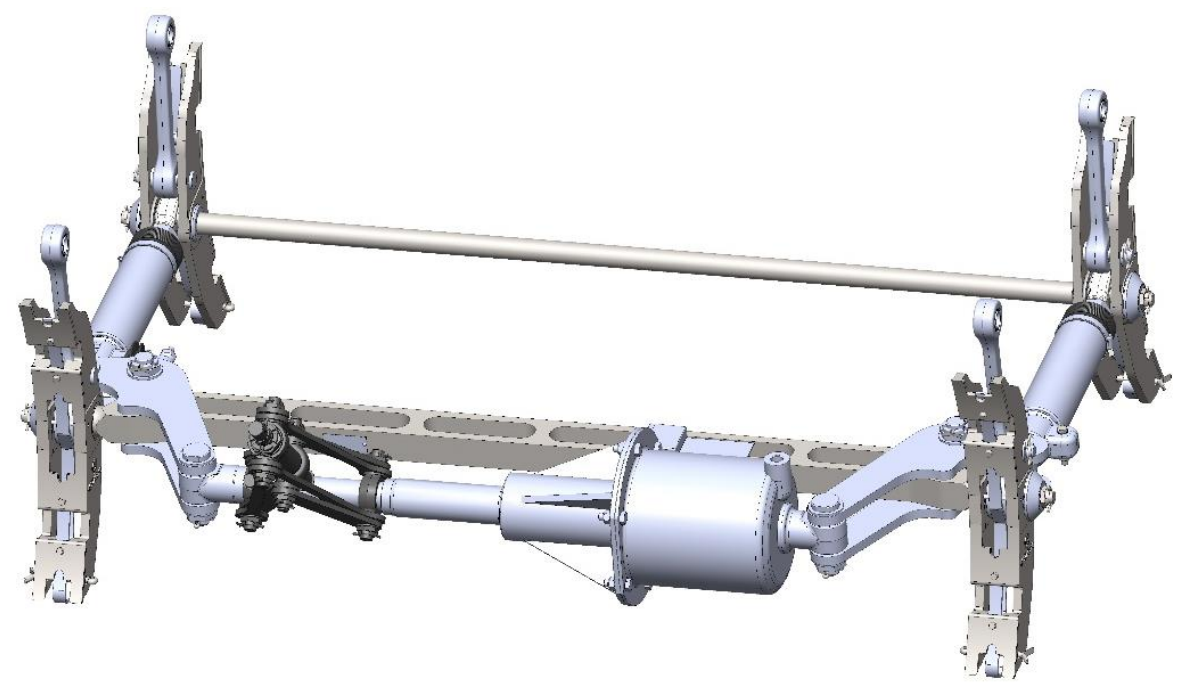

Fig. 4. Model of innovative brake system IBB10 with platform hand brake [6] 
The activation of the platform hand brake should be performed from the platform of the freight wagon by turning the hand wheel through a box with conical gears and a telescope cardan shaft, which is connected with the spindle of the platform hand brake mechanism. In Figure 5 is shown a model of Y25 bogie with installed brake system IBB10 with platform hand brake and connecting components for activation with segment of the wagon platform. By turning the hand wheel, the torque is transmitted through the gears and the cardan shaft to the spindle of the platform hand brake mechanism activates (extends) the brake cylinder. This mechanism is connected to the piston rod and during service brake it moves together with the piston rod. The connection of the hand brake to the platform is necessary to be performed with a telescope cardan shaft in order not to decrease the degrees of freedom of the brake system during braking and releasing.

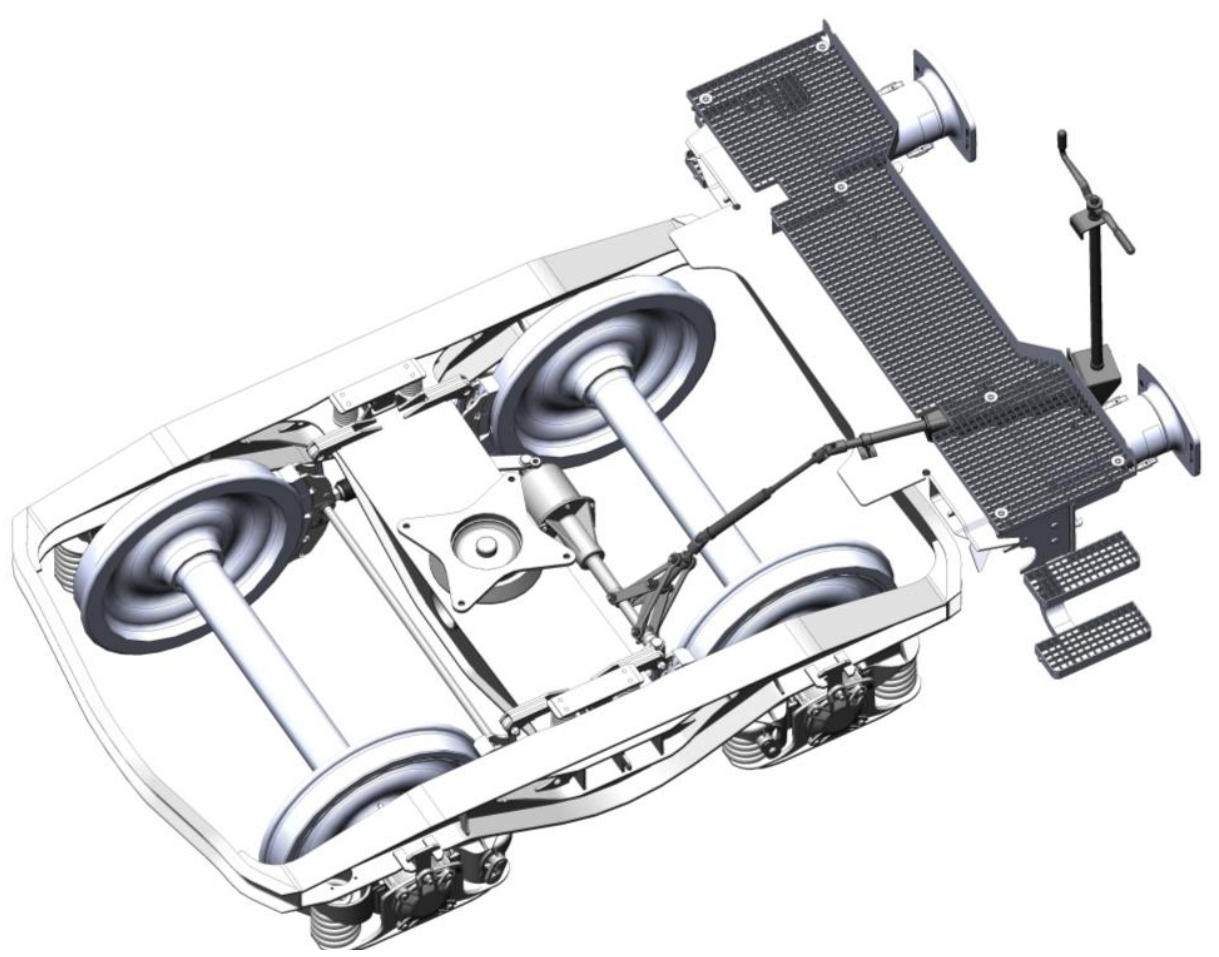

Fig. 5. Model of Y25 bogie with installed brake system IBB10 with platform hand brake and connection components for activation with segment of the wagon platform

\section{MULTI-BODY SIMULATION OF THE INNOVATIVE BRAKE SYSTEM}

In the multi-body simulation is used finite element method, which is a key method for design, homologation and research in the field of railways and railway vehicles [7]. This type of simulation is one of the most advanced methods for developing and optimizing a designed mechanism. Because the brake system is a subject of large static and dynamic loads during the braking process, it is necessary that the brake system has undergone multi-body simulation before the prototype is produced. Figure 6 shows a 3D model of the innovative brake system IBB10 with platform hand brake for multi-body simulation.

The main components of the innovative brake system IBB10 with platform hand brake, which are shown in Figure 6 and are evaluated in the simulation are the following:

1. Four hangers on which the brake system are supported.

2. Special rubber bushings mounted on the hangers to provide freedom of movement and reduce vibration.

3. Brake shoes that in the 3D model are shown with an approximate geometry.

4. Primary beam which is one of the most loaded elements in the system.

5. Secondary beam which due to the slack adjusters location is not subject to high loads.

6. Two slack adjusters that in the 3D model are presented as rigid bodies with a weight corresponding to the real one. Given the complexity of the slack adjusters that would greatly comp- 
licate the simulation, the internal components will not be analyzed.

7. Brake cylinder which is connected with four levers to the primary beam.

8. Four levers which perform multiplication of the force from the brake cylinder to the slack adjustters. In addition to the loads in the horizon- tal direction, under the action of vertical vibrations, they are heavily loaded in the vertical direction.

9. Platform hand brake which due to the large number of levers and connection elements will be represented as a rigid body with a weight equal to the real one.

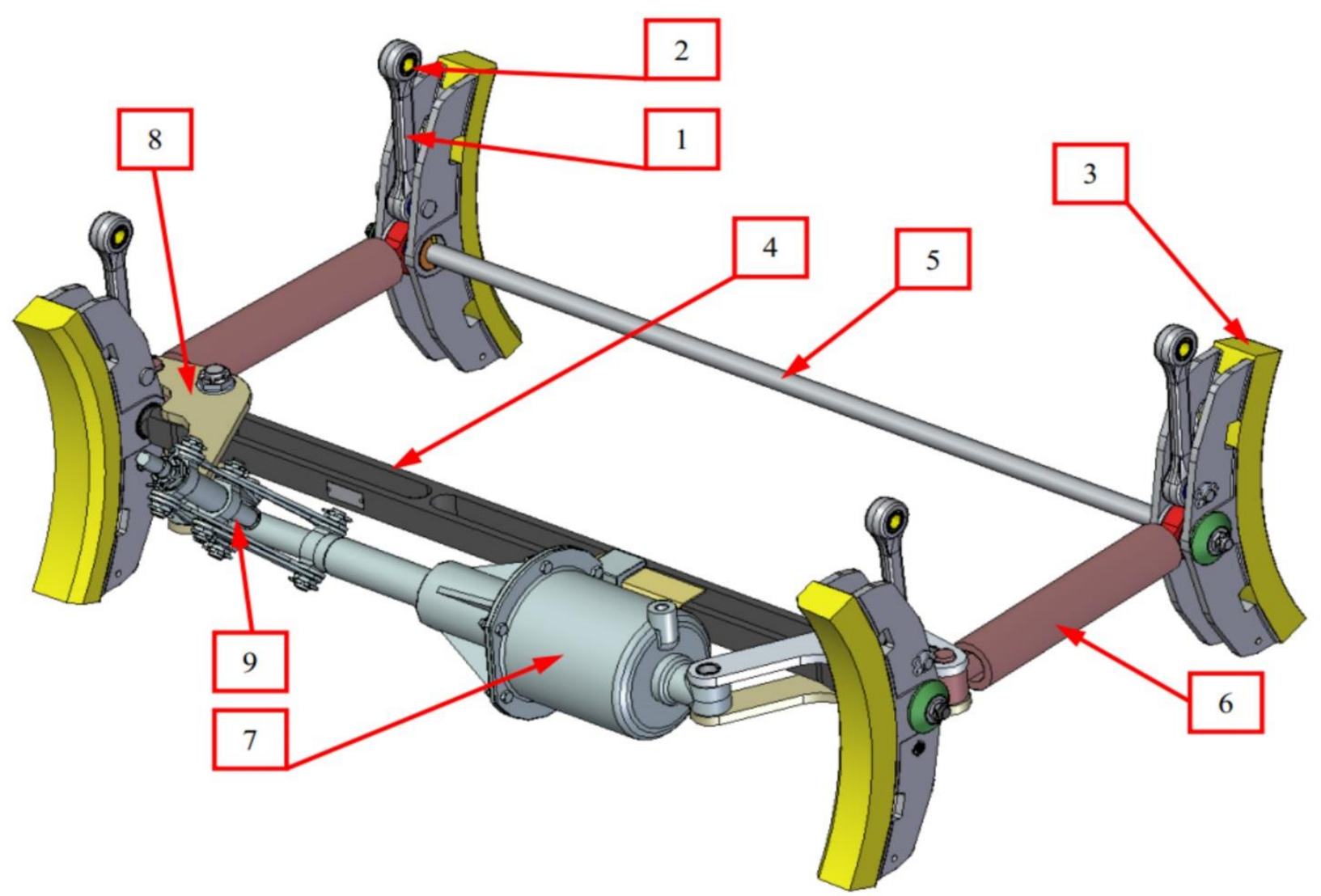

Fig. 6. 3D model of IBB10 with platform hand brake for simulation [10]

Considering that the brake system is in direct relation with the bogie of the wagon, it is necessary to include in the simulation all main elements that are in direct relation to the brake system and the rail.

The accelerations to be included in the simulation are according to BS EN 13749 [9]. This standard defines the accelerations in each direction which are used in the calculation and are divided into two classes. For components related to the bogie are considered the acceleration values in Table 1, while the components related to the wheelset are the acceleration values listed in Table 2 . It is obvious that the accelerations of the wheelset related components are greater (especially in the vertical direction) because the wheels are the most exposed components of the entire wagon and are directly affected by all irregularities of the rail. All components connected to the bogie are subject to minor accelerations because there are suspension springs between the body of the bogie and the axles of the wheels.

As the brake system is connected to the bogie, the accelerations shown in Table 1 are most commonly used (when the system is released). In case of braking, due to the frictional contact between the wheels and the brake shoes, the acceleration of the wheels is transmitted to the brake system. In this case there will be combined acceleration values from Table 1 and Table 2. Also, becuse of the dynamic nature of the braking process caused by the contact of the brake system and the rotating wheels, there are additional loads which need to be considered. 
Ta ble 1

Accelerations according to EN 13749 - Table D.1 (bogie mounted parts) [9]

\begin{tabular}{lcc}
\hline \hline Direction & $\begin{array}{c}\text { Extreme } \\
\text { acceleration }(\mathrm{g})\end{array}$ & $\begin{array}{c}\text { Continual acting } \\
\text { acceleration }(\mathrm{g})\end{array}$ \\
\hline Vertical & \pm 20 & \pm 6 \\
Transversal & \pm 10 & \pm 5 \\
Longitudinal & \pm 5 & \pm 2.5 \\
\hline \hline
\end{tabular}

Ta b le 2

Accelerations according to EN 13749 - Table D.2 (wheelset mounted parts) [9]

\begin{tabular}{lcc}
\hline \hline Direction & $\begin{array}{c}\text { Extreme } \\
\text { acceleration }(\mathrm{g})\end{array}$ & $\begin{array}{c}\text { Continual acting } \\
\text { acceleration }(\mathrm{g})\end{array}$ \\
\hline Vertical & \pm 70 & \pm 25 \\
Transversal & \pm 10 & \pm 5 \\
Longitudinal & \pm 10 & \pm 5 \\
\hline \hline
\end{tabular}

Figure 7 shows 3D model of Y25 bogie, which includes the innovative brake system IBB10 with platform hand brake. This 3D model does not show the springs between the wheel axles and the body of the bogie to reduce the complexity of the entire system, but during the simulation itself, the functionality of the springs is taken into account.

The dynamic simulation model has a role to simulate the analyzed system as realistically as possible. In this case, during the simulation, it is assumed that the wheels are in contact with the rail and rotate in the direction shown in Figure 8. In the middle area where the spherical joint of the bogie is positioned is added a load in the form of a mass dummy. This mass dummy simulates the load, expressed as half of the mass of the entire wagon (Figure 9).

For a clearer view of the analyzed model, in Figure 9 is shown in several views, where the main components of the 3D model are described.

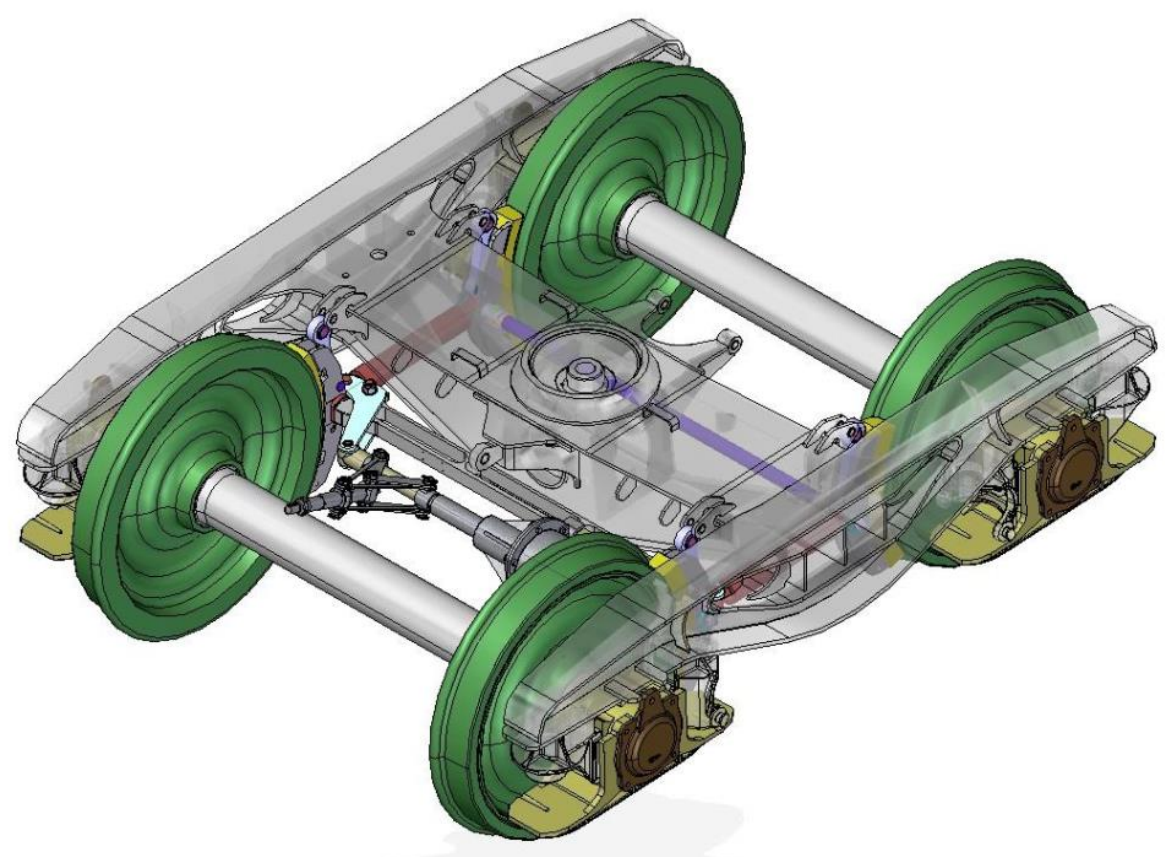

Fig. 7. 3D model of Y25 bogie and IBB10 with platform hand brake for simulation [10]
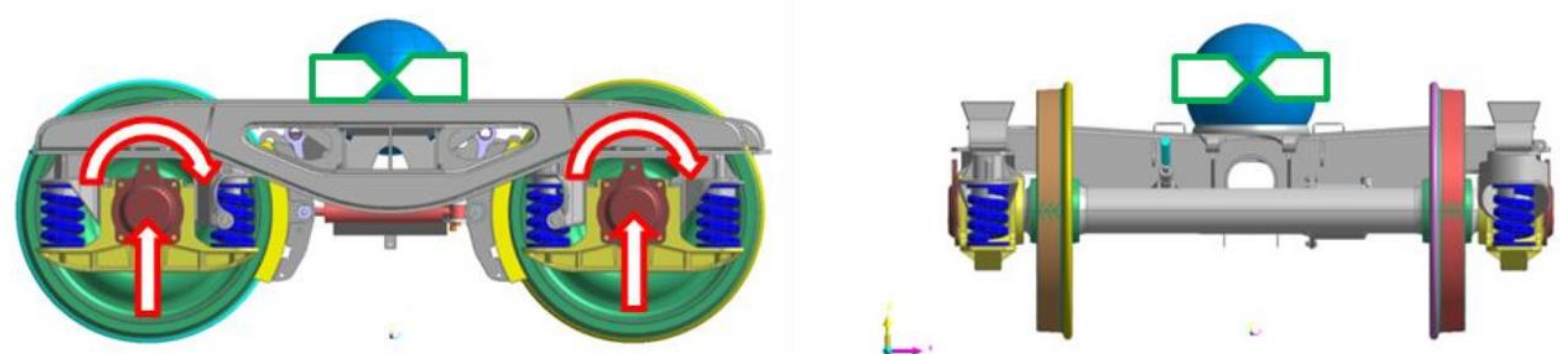

Fig. 8. Supports and constraints on the 3D model of the bogie and IBB10 for simulation [10] 

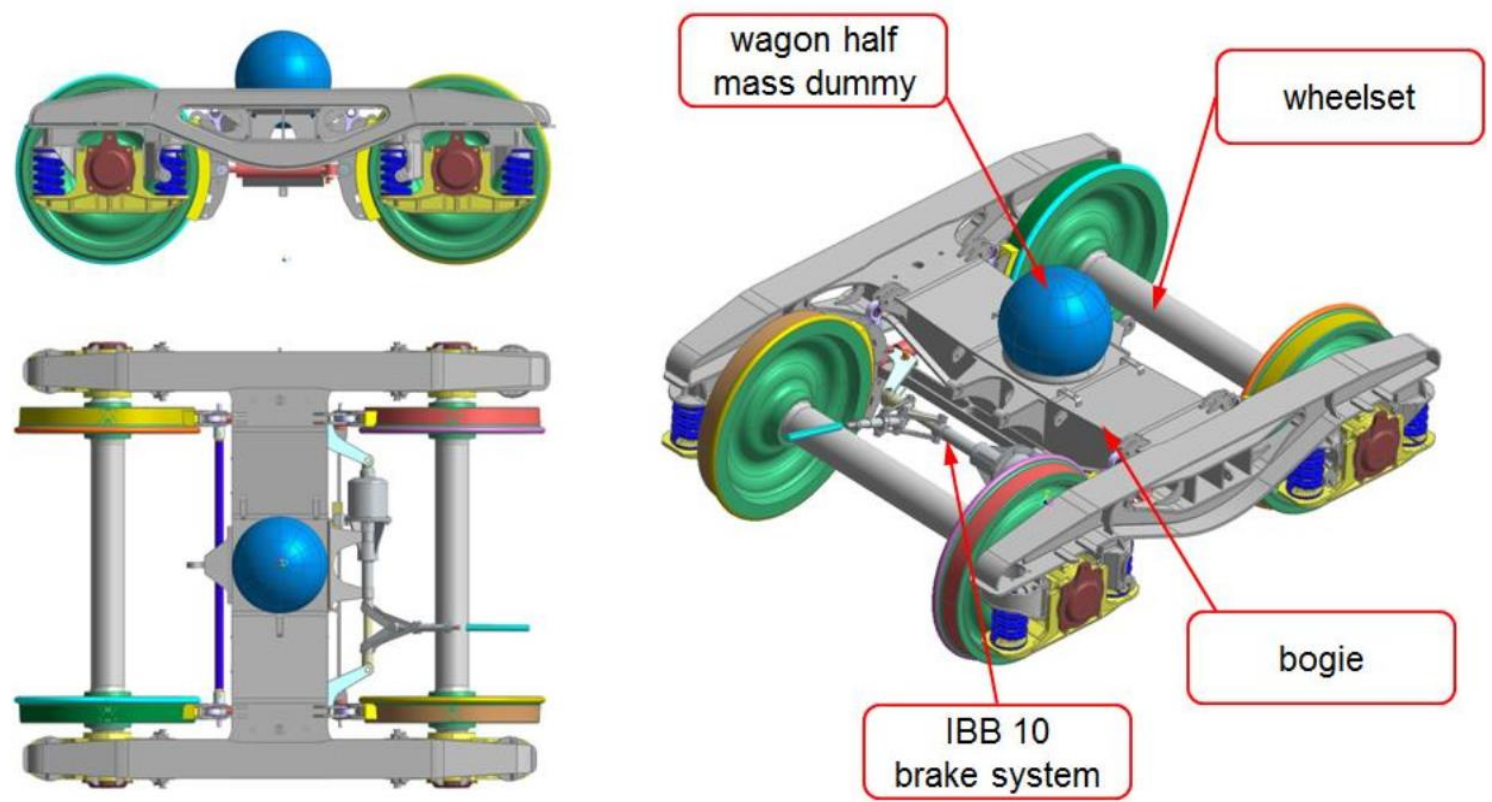

Fig. 9. Description of the 3D model for multi-body simulation [10]

Given that the mass of the wagon is variable, depending on whether it is empty or loaded, knowing the stiffness characteristics of the springs on the bogie, the position of the entire analyzed system can be simulated. Figure 10 shows the height of the IBB10 in relation to the wheel axis in the case of empty wagon $(m=26 \mathrm{t})$ and in fully loaded wagon
( $m=90 \mathrm{t}$ ). In fully loaded static position the height of the bogie is $30 \mathrm{~mm}$ lower compared to the empty wagon. Because in the analysis is included only one bogie, while the wagon has two, the weights that will act on one bogie will be two times smaller than the indicated ones.
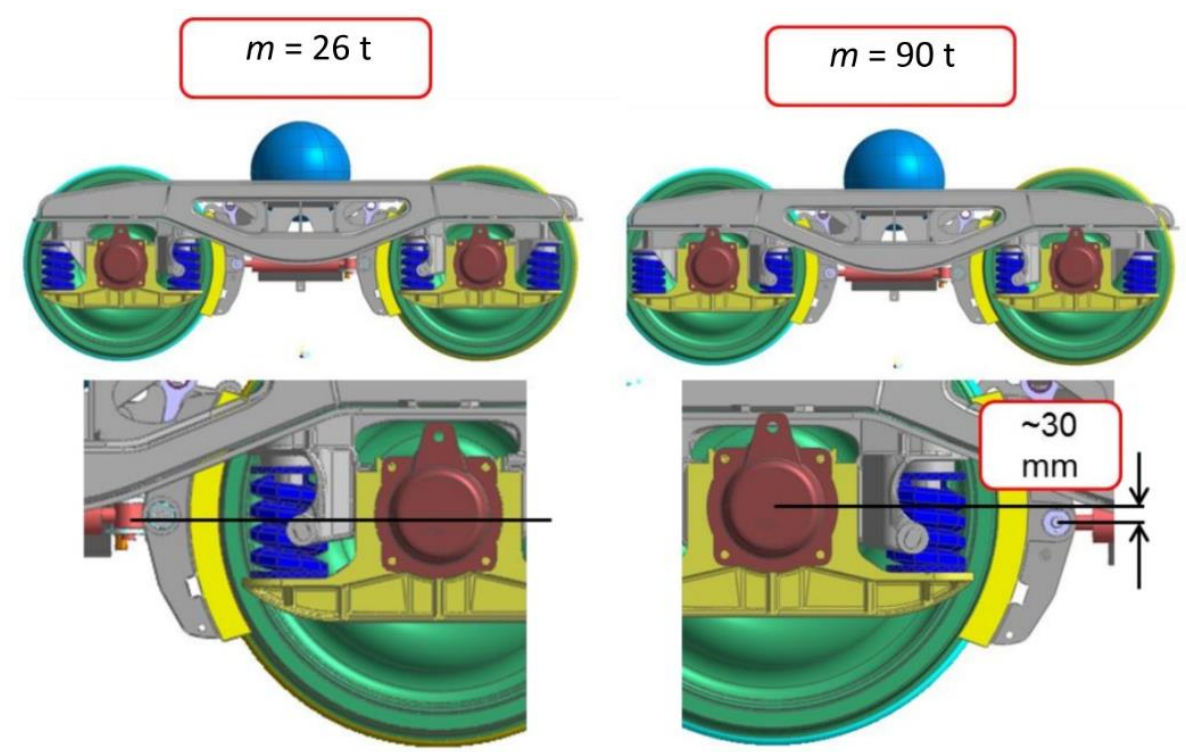

Fig. 10. Height of the bogie relative to the wheel axis on empty wagon (left) and fully loaded wagon (right) [10]

Taking the above parameters, in order to verify the connection of the elements in the 3D model, it is necessary to make an initial simulation. Figure 11 shows the force on the hangers (position 1 in Figure 6) due to gravity load. The results of this initial simulation show a good correspondence with the analytical calculation.

It should be noted that there is a different load force on the hangers because there is unequal distribution of the masses due to the location of the 
brake cylinder (and the hand brake). The $\mathrm{H}_{1}$ and $\mathrm{H}_{2}$ hangers which are located near the primary beam are more loaded (in a static position with force $F \approx$ $750 \mathrm{~N}$ ), while the hangers located near the secondary beam $\mathrm{H}_{3}$ and $\mathrm{H}_{4}$ are less loaded (in a static position $F \approx 250 \mathrm{~N}$ ). The goal of correctly setting the initial conditions is to get as much accurate results as possible. The results of such analysis are obtaining the stresses and deformations in the analyzed cases. More important is the get the maximum stresses in the analyzed cases, but in some cases when the system needs to have a smaller or larger elasticity, deformations play more important role.

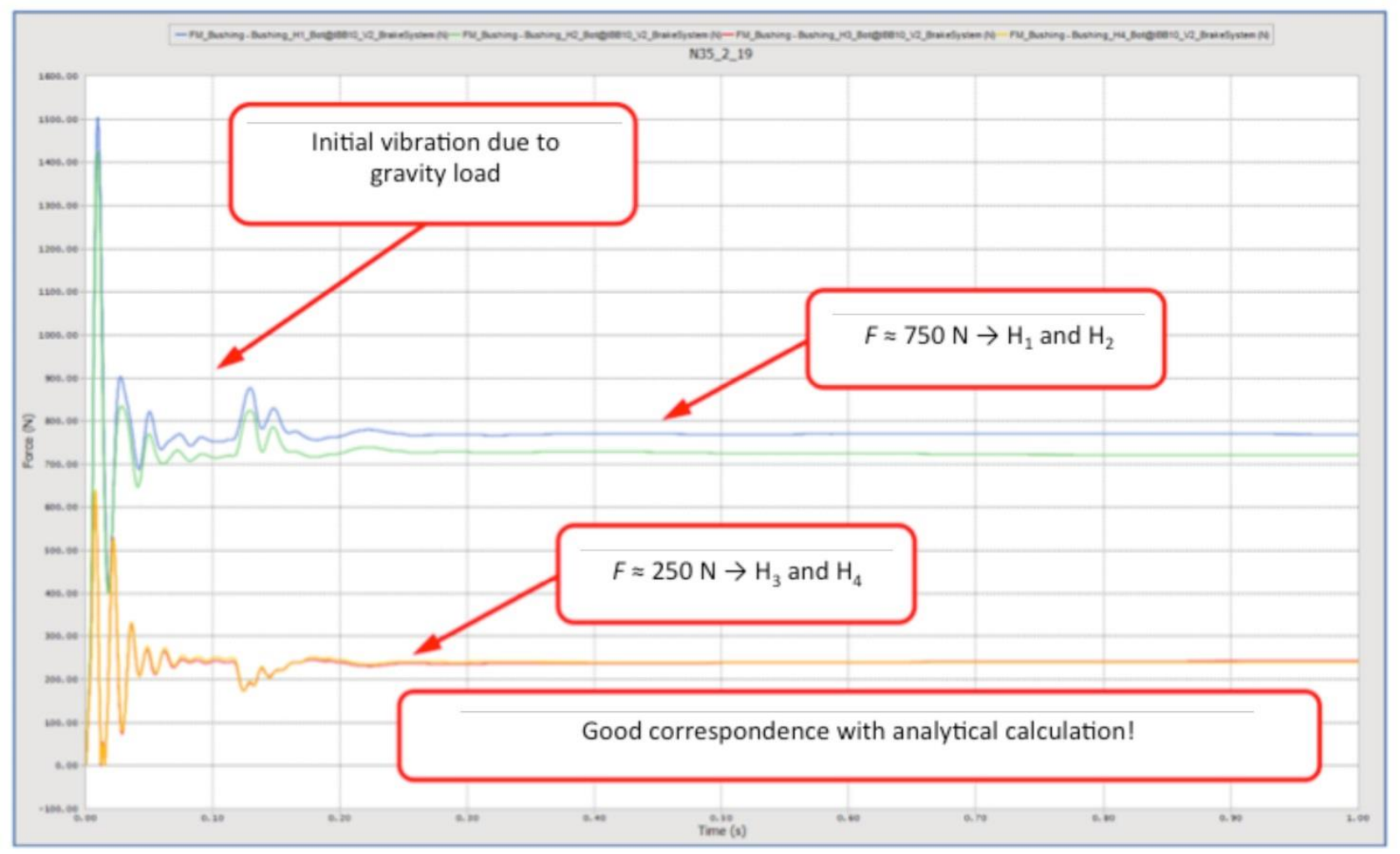

Fig. 11. Hanger force due to gravity load [10]

Figure 12 shows deformations of the levers which are connecting the brake cylinder to the primary beam and the slack adjusters. As can be seen, the maximum deformation is $\varepsilon \approx 3.7 \mathrm{~mm}$ and it occurs in the case of extreme vertical vibrations. The design of this brake system limits these deformations due to cylinder holder which is in a sliding connection with an U-profile which is mounted on the primary beam. This holder limits the movement and deformation of the levers in a vertical direction. This is shown in Figure 13.

Obtaining the maximum stresses from the load cases is of great importance in order to create optimized design and to make maximum utilization of the material. In this way lighter and cheaper products can be designed, which is a very noticeable trend nowadays. Figure 14 shows the stresses of the levers in extreme load case

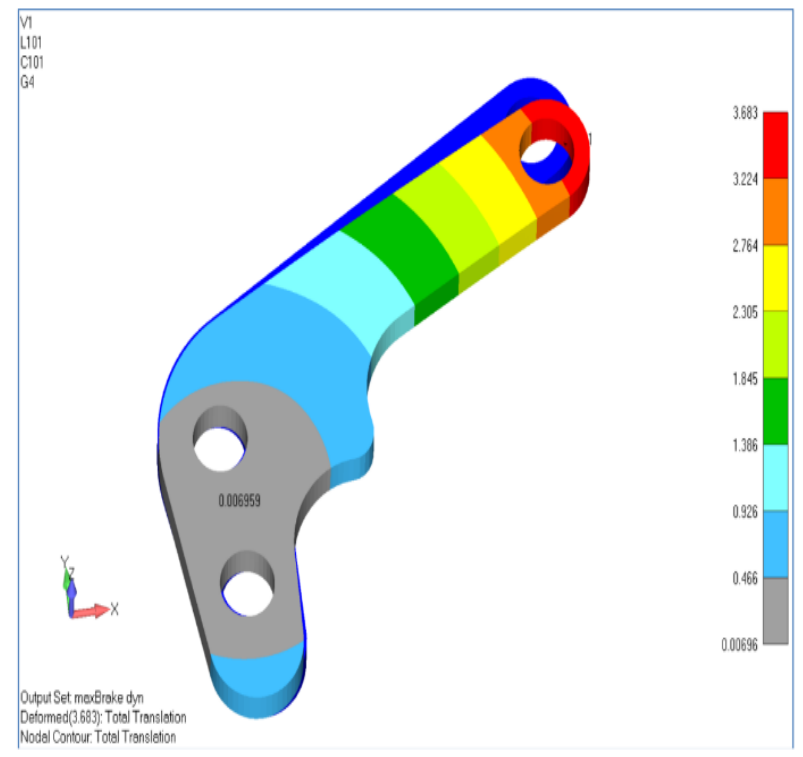

Fig. 12. Lever - deformation in extreme load case [10] 


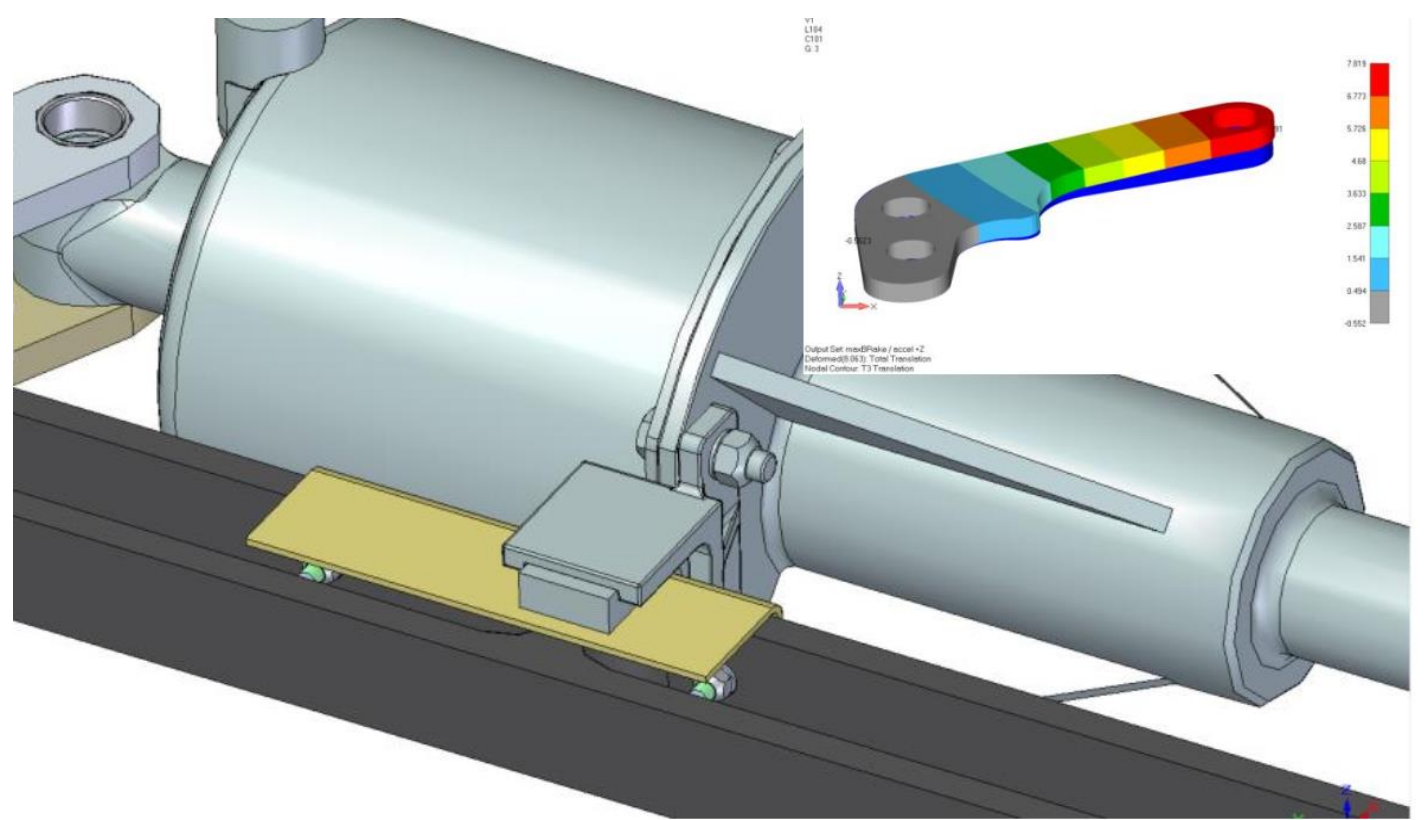

Fig. 13. Brake cylinder holder limits the deformation of the levers [10]
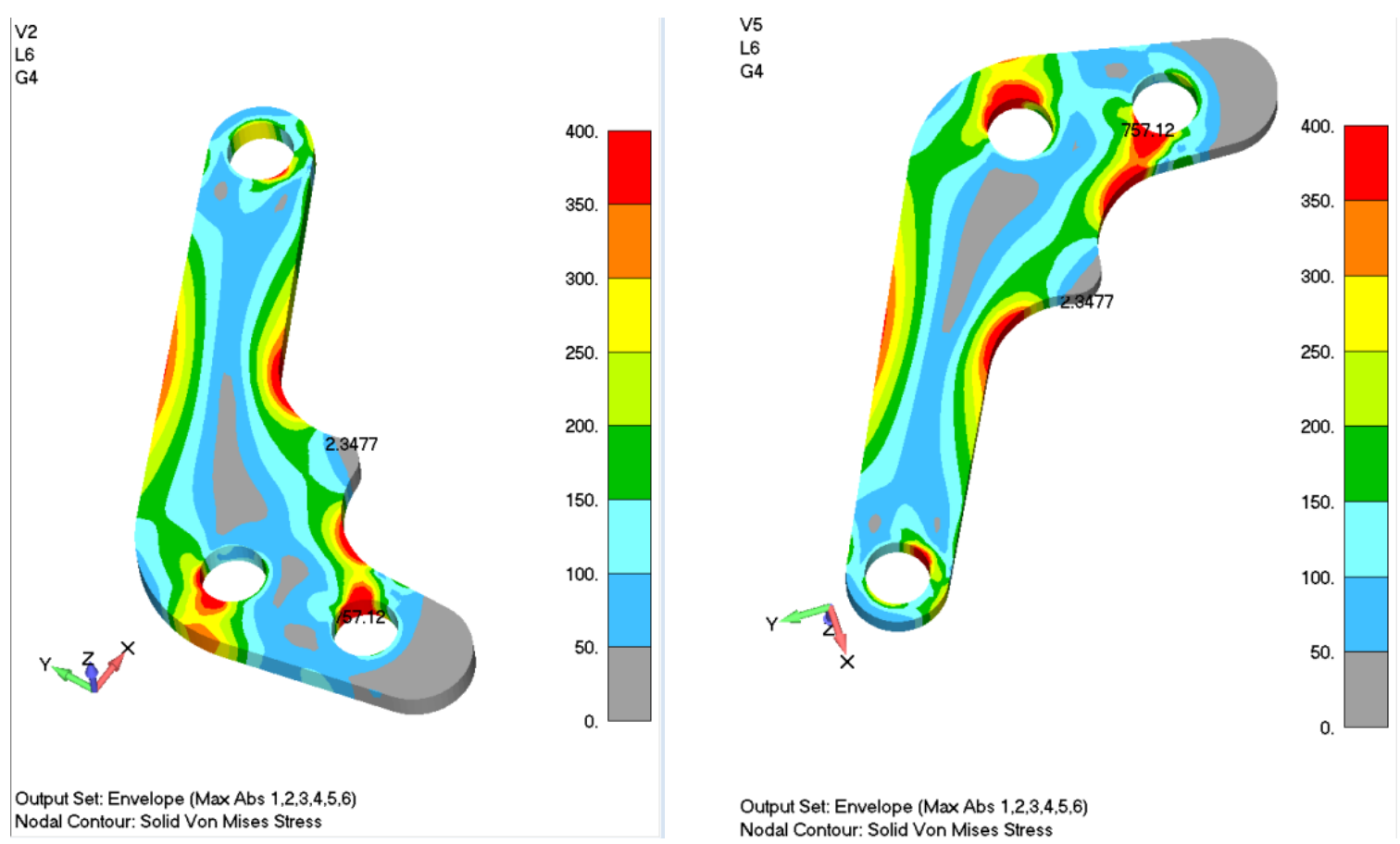

Fig. 14. Lever - stresses during extreme load case [10]

\section{CONCLUSION}

This paper shows one part of the development of a complex mechanical system - an innovative brake system for rolling stock. Considering that the brake systems are of great importance for the safety of rail traffic and are exposed to large static and dynamic loads under external conditions, the development of such system is a long and complex process.
In the process of developing a brake system, the most important asset is to use the most advanced softwares, methods and techniques. Multi-body simulation together with finite element analysis is one of the key methods for design, homologation and research in the field of railways and railway vehicles. Multi-body simulation can replace very expensive tests and measurements of the railway vehicle. Nowadays almost every newly developed product for the railway industry goes through multi- 
body simulation. The results of the simulation indicate that the brake system satisfies the UIC standard criteria and meets the requirements of the customers. By successfully passing the simulation, there is a significant increase of the chances for successfully completing the validation tests and successfully palcing this innovative brake system on the market.

\section{REFERENCES}

[1] Chary, R., Khan, E.: Design and Analysis of Train Brake System, International Journal of Advanced Research and Innovation, Vol. 7, Issue 3, pp. 27-33 (October 2014).

[2] Wynd, D., Connelly, M.: Advanced Bogie Brakes, Proceedings, Conference on Railway Engineering, Wellington, September 12-15, 2010.

[3] Sharma, R. C., Dhingra, M., Pathak, R. K.: Braking Systems in Railway Vehicles, International Journal of Engineering Research \& Technology, Vol. 4, Issue 1, pp. 204 211 (January 2015).

[4] Дуковски, В.: Менаименӣ на развојоӣ на нови йроизводи, Универзитет „Св. Кирил и Методиј“, Скопје, 2001.

[5] Smileski, S., Smileski, T.: Integrated bogie brake and slack adjuster for the use with said integrated bogie brake, Patent WO 2013098350 A2, December 27, 2011.

[6] Smileski, T., Rakipovski, R., Mičić, M.: Comparison of Classical Brake for Freight Wagons with New Integrated
Bogie Brake IBB10 for Freight Wagons, RAILKON `16, Niš, October 13-14, 2016.

[7] Weidemann, C.: State of the Art Railway Vehicle Design with Multi-Body Simulation, Journal of Mechanical Systems for Transportation and Logistics, Vol. 3, No 1, pp. 12-26 (2010).

[8] Bhuiyan, N.: A framework for successful new product development, Journal of Industrial Engineering and Management (JIEM), Volume 4, Issue 4, pp. 746-770 (2011).

[9] BS EN 13749:2011, Railway Applications - Wheelsets and Bogies. Method of specifying the structural requirements of bogie frames, 2011.

[10] Artner, W.: MBD/FEA-Analysis IBB10 Brake System New Design, Report a 13010 RV0, November 2013.

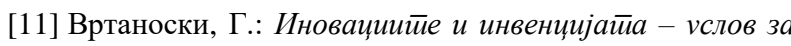
излез од економскайа криза, предавања на постдипломски студии (ПЛМ), Развој и менаимент на производите, Универзитет „Св. Кирил и Методиј“, Машински факултет, Скопје, 2012.

[12] Kim, L.: Imitation to Innovation - The Dynamics of Korea's Technological Learning, Harvard Business School Press, 1997.

[13] Lunden, R., Vernersson, T.: Mechanical braking systems development and challenges, Presentation at 19th Nordic Seminar on Railway Technology, Chalmers University of Technology, Lulea, September 14-15, 2016.

[14] Pugi, L., Palazzolo, A., Presciani, P., Fioravanti, D.: Simulation and optimization of railway pneumatic braking system, World Congress for Railway Research WCRR2006, Montreal, June 2006. 
